\title{
HERPETOFAUNAL DIVERSITY IN SELECTED HABITAT TYPES IN NOTHERN PART OF THE GIRITALE NATURE RESERVE
}

\section{By}

Mathota Gamaralalage Theja Hemamali Abayarathna

Thesis submitted to the University of Sri Jayewardenepura for the award of the Degree of Master of Philosophy in Zoology in April 2009. 


\section{DECLARATION}

"The work described in this thesis was carried out by me under the supervision of Dr.

(Mrs.) W .A. D. Mahaulpatha, Senior lecturer, Department of Zoology, Faculty of Applied Sciences, University of Sri Jayewardenepura, Nugegoda and Dr. (Mrs.) T. V. Sundarabarathy, Head of the Department, Department of Biology, Faculty of Applied Sciences, Rajarata university of Sri Lanka, Mihintale and a report on this has not been submitted in whole or in part to any university or any other institution for another Degree/Diploma"

26.........8.8.9...

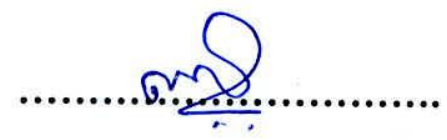

Date

Signature 


\section{DECLARATION}

"I/We certify that the above statement made by the candidate is true and that this thesis is suitable for submission to the University for the purpose of evaluation".

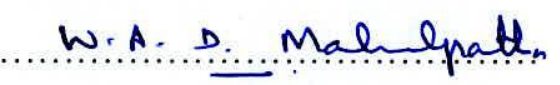

Signature

(Dr.W.A.D.Mahaulpatha)

$26 . \therefore 10 \ldots 09 \ldots$

Date

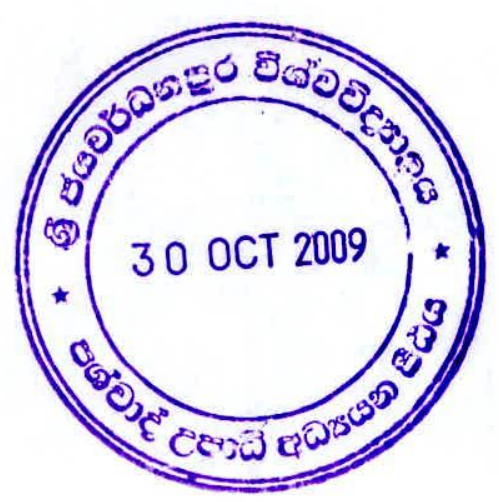




\section{DECLARATION}

I certify that the above statement made by the candidate is true and the thesis is suitable for submission to the University for the purpose of evaluation.

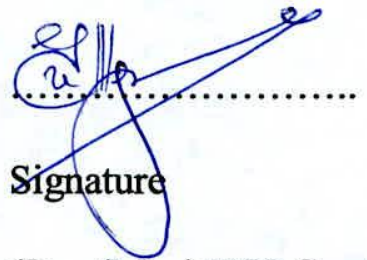

(Dr. (Mrs.) T.V. Sundarabarathy)

$27 / 10 / 2009$ 
LIST OF TABLES vi

LIST OF FIGURES - ix

LIST OF PLATES Xi - xi

ACKNOWLEDGEMENT $\quad$ xii

ABSTRACT Xiii

1.0 INTRODUCTION 1

2.0 LITERATURE REVIEW 4

2.1 Geography of Sri Lanka 4

$\begin{array}{ll}\text { 2.2 Physiography of Sri Lanka } & 4\end{array}$

2.3 Climatic zones of Sri Lanka 5

2.4 Biodiversity of Sri Lanka 5

$\begin{array}{ll}\text { 2.5 Herpetofauna of Sri Lanka } & 6\end{array}$

2.5.1 Amphibians $\quad 7$

2.5.1.1 Amphibian diversity of Sri Lanka $\quad 7$

2.5.2 Reptiles 9

2.5.2.1 Reptile diversity of Sri Lanka 9

2.6 Importance of conducting surveys 11

$\begin{array}{ll}2.7 \text { Treats to herpetofauna } & 13\end{array}$

$\begin{array}{ll}2.8 \text { Research gaps on herpetofauna } & 14\end{array}$

$\begin{array}{ll}2.9 \text { Objectives of the study } & 16\end{array}$

$\begin{array}{ll}\text { 3.0 METHODOLOGY } & 17\end{array}$

$\begin{array}{ll}\text { 3.1 Study area } & 17\end{array}$ 
$\begin{array}{ll}3.1 .1 \text { Geology and soil } & 18\end{array}$

$\begin{array}{ll}3.1 .2 \text { Terrain } & 19\end{array}$

$\begin{array}{ll}3.1 .3 \text { Climate } & 20\end{array}$

3.1.4 Hydrology and water resources $\quad 20$

3.2 Microhabitat measurements 23

$\begin{array}{ll}\text { 3.3 Environmental parameters } & 23\end{array}$

3.4 Amphibian and reptile sampling 23

$\begin{array}{ll}\text { 3.4.1 Quadrates } & 24\end{array}$

3.4.2 Visual Encounter Surveys $\quad 24$

3.4.3 Pit fall traps $\quad 25$

3.4.4 Opportunistic data $\quad 25$

3.5 Identification of herpetofauna 25

$\begin{array}{ll}\text { 3.6 Analysis } & 26\end{array}$

3.6.1 Habitat data $\quad 26$

$\begin{array}{ll}\text { 3.6.2 Diversity indices } & 26\end{array}$

3.6.3 Relative abundance of amphibians and reptiles $\quad 27$

3.6.4 Similarity of amphibian community and reptile community $\begin{array}{ll}\text { between habitats } & 27\end{array}$

3.6.5 Correlation of the amphibian and reptile population with ambient temperature, rainfall and humidity 28

$\begin{array}{lr}\text { 4.0. RESULTS } & 29\end{array}$

$\begin{array}{lr}\text { 4.1 Habitat variables } & 29\end{array}$

$\begin{array}{ll}\text { 4.2 Amphibians } & 35\end{array}$

4.2.1 Amphibians recorded at the Giritale Nature Reserve $\quad 35$ 
4.2.2 Diversity indices and distribution of amphibians between habitats 37

4.2.3 Relative abundances of amphibians

4.2.4 Similarity of the amphibian structure between habitats

4.2.5 Distribution of amphibians between two monsoonal seasons

4.2.6 Variation of the amphibian population, species richness and density with the ambient temperature

4.2.7 Variation of the amphibian population, species richness and density with the rainfall

4.2.8 Variation of the amphibian population, species richness and density with the humidity

\subsection{Reptiles}

4.3.1 Reptiles recorded at the Giritale Nature Reserve

4.3.2 Diversity indices and distribution of reptiles between habitats

4.3.3 Relative abundances of reptiles

4.3.4 Similarity of the reptile structure between habitats

4.3.5 Distribution of reptiles between two monsoonal seasons

4.3.6 Variation of the reptile population, species richness and density with the ambient temperature

4.3.7 Variation of the reptile population, species richness and density with the rainfall

4.3.8 Variation of the reptile population, species richness and density with the humidity

\subsection{DISCUSSION}


5.2.1 General aspect

5.2.2 Diversity indices and distribution of amphibians between habitats 77

$\begin{array}{ll}\text { 5.2.3 Relative abundances of amphibians } & 81\end{array}$

5.2.4 Similarity of the amphibian structure between habitats 82

5.2.5 Distribution of amphibians between two monsoonal seasons $\quad 82$

5.2.6 Variation of the amphibian population, species richness and density with the ambient temperature

5.2.7 Variation of the amphibian population, species richness and density with the rainfall

5.2.8 Variation of the amphibian population, species richness and density with the humidity

5.3.1 General aspect

5.3.2 Diversity indices and distribution of reptiles between habitats

5.3.3 Relative abundances of reptiles

5.3.4 Similarity of the reptile structure between habitats

5.3.5 Distribution of reptiles between two monsoonal seasons

5.3.6 Variation of the reptile population, species richness and density with the ambient temperature

5.3.7 Variation of the reptile population, species richness and density with the rainfall

5.3.8 Variation of the reptile population, species richness and density with humidity 
6.0 CONCLUSIONS

7.0 REFFERENCES

8.0 APPENDICES 


\section{LIST OF TABLES}

Table No.

Title

Page

1 Mean percentage cover $( \pm \mathrm{SD}$ ) of building, water, tree, log, bare ground, grass, termite mound, stone and paddy of the different habitat types at the Giritale Nature Reserve from May 2006 to April 2008.

2 Fisher's PLSD tests for environmental variables measured in each habitat at Giritale Nature Reserve from May 2006 to April 2008.

3 Amphibian species composition (listed in standard taxonomic order) recorded at the Giritale Nature Reserve from May 2006 to April 2008.

4 Composition of amphibian community with total number of individuals, species richness, Berger -Parker Index of dominance, density, Shannon's diversity index $\left(\mathrm{H}^{\prime}\right)$ and Shannon evenness Index $(\mathrm{E})$ at different habitats of the Giritale Nature Reserve .

5 Relative abundance and rank of the amphibians at the Giritale Nature Reserve from May 2006 to April 2008.

6 Similarity of the amphibian structure between four different habitats at the Giritale Nature Reserve. 
7 Amphibian population recorded in two monsoonal seasons during the period from May 2006 to April 2008 at the Giritale Nature Reserve .

8 Variation of the amphibian population, species richness and the density with the ambient temperature between habitats at the Giritale Nature Reserve from May 2006 to April 2008.

9 Variation of the amphibian population, species richness and the density with the rainfall at the Giritale Nature Reserve from May 2006 to April 2008.

10 Variation of the amphibian population, species richness and the density 51 with the relative humidity at the Giritale Nature Reserve from May 2006 to April 2008.

11 Reptile species composition (listed in standard taxonomic order) recorded at the Giritale Nature Reserve from May 2006 to April 2008.

12 Composition of reptile community with total number of individuals, species richness, Berger -Parker Index of dominance, density, Shannon's diversity index $\left(\mathrm{H}^{\prime}\right)$ and Shannon evenness Index (E) at different habitats of the Girithale Nature Reserve. 
13 Relative abundance and rank of the reptiles at the Giritale Nature Reserve from May 2006 to April 2008.

14 Similarity of the reptile structure between four different habitats at the Giritale Nature Reserve from May 2006 to April 2008.

15 Reptile population recorded in two monsoonal seasons during the period from May 2006 to April 2008 at the Giritale Nature Reserve .

16 Variation of the reptile population, species richness and the density with the ambient temperature between habitats at the Giritale Nature Reserve from May 2006 to April 2008.

17 Variation of the reptile population, species richness and the density with the rainfall at the Giritale Nature Reserve from May 2006 to April 2008.

18 Variation of the reptile population, species richness and the density with the relative humidity at the Giritale Nature Reserve from May 2006 to April 2008. 


\section{LIST OF FIGURES}

$\begin{array}{lll}\text { Figure Title Page } & \text { Par }\end{array}$

1 Map of the study site

2 Cluster analysis for grouping habitat variables into major habitat categories of Giritale Nature Reserve

3 Species accumulation curves for amphibians recorded from different habitats of the Giritale Nature Reserve from May 2006 to April 2008

4 Rank abundance curves for amphibians recorded from four different habitats of Giritale Nature Reserve from May 2006 to April 2008

5 Average number of amphibians recorded in two monsoonal seasons from May 2006 to April 2008

6 Total number of amphibians recorded and variation of the monthly rainfall from May 2006 to April 2008 
7 Species accumulation curves for reptiles recorded from different habitats of the Giritale Nature Reserve from May 2006 to April 2008

8 Rank abundance curves for reptiles recorded from four different habitats of the Giritale Nature Reserve from May 2006 to April 2008

9 Average number of reptiles recorded in two monsoonal season. in Giritale Nature Reserve

10 Total number of reptiles recorded and variation of the monthly rainfall from May 2006 to April 2008 


\section{LIST OF PLATES}

$\begin{array}{lll}\text { Plate no Title Page } & \text { Te }\end{array}$

$1 \quad$ Grassland habitat in Giritale Nature Reserve $\quad 124$

2 Home gardens in Giritale Nature Reserve 124

3 Forest habitat in Giritale Nature Reserve $\quad 124$

4 Paddy fields in Giritale Nature Reserve $\quad 124$

$\begin{array}{ll}\text { 5. Duttaphrynus melanostictus } & 124\end{array}$

$\begin{array}{lll}6 & \text { Fejervarya limnocharis } & 124\end{array}$

$7 \quad$ Hoplobatrachus crassus $\quad 125$

$8 \quad$ Polypedatus maculates $\quad 125$

$9 \quad$ Kaloula taprobanica $\quad 125$

10 Rhinophis oxyrhynchus 126

11 Dasia halianus 126

12 Geochelon elegans $\quad 126$

13 Dendrilapis tristris $\quad 126$

14 Hemidactylus leschenaultii 126

15 Hemidactylus triedrus $\quad 126$

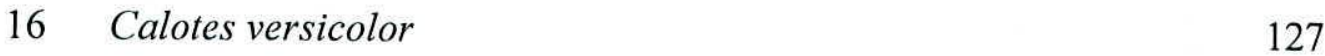

17 Eutropis macularia $\quad 127$

18 Boiga forsteni 127

19 Daboia russellii $\quad 127$

20 Varanus bengalensis $\quad 127$ 


\section{ACKNOWLEDGEMENT}

I am indebted to the University of Sri Jayewardenepura, Gangodawila, Nugegoda and to the academic and non academic staff of the department of zoology, University of Sri Jayewardenepura for providing the necessary facilities to conduct this study. I wish to extend my sincere gratitude to my supervisors Dr.(Mrs.) W.A.D.Mahaulpatha, Senior lecturer, Faculty of Applied Sciences, University of Sri Jayewardenepura and Dr. (Mrs.) T.V. Sundarabarathy, Head of the department, Department of Biology, Faculty of Applied Sciences, Rajarata University of Sri Lanka, for their invaluable guidance and precious encouragement. I sincerely acknowledge to Mr. Anslem De Silva, for his guidance throughout the research, provision of literature and help in identification of the specimens. I convey my gratitude to Dr. W.M.T.Mahaulpatha, for his invaluable assistance throughout the study. I also wish to extend my sincere thanks to the Director, Department of Wildlife and Conservation, for granting me permission to carry out this research at the. I wish to extend my thanks to all the staff members of the Wildlife Training Centre, Giritale, for their help in various ways to complete this study. I greatly appreciate the support given by my colleagues Miss. D.M.T. Dassanayaka, Miss. A.V.D.J.Indika, Miss. O.A.A.S.Sarathchandra and Mr. R. Hedeniya to complete this research successfully. Finally, I wish to thank my husband who encouraged and helped me through out the research. 


\title{
HERPETOFAUNAL DIVERSITY IN SELECTED
}

HABITAT TYPES IN NOTHERN PART OF THE

\author{
GIRITALE NATURE RESERVE
}

\section{Mathota Gamaralalage Theja Hemamali Abayarathna}

\begin{abstract}
One of the biggest drawbacks in conserving our valuable herpetofauna is the lack of knowledge, since only a fraction of the amphibian and reptile species present in different areas of the country is hitherto known to science. Hence, it is essential to gather information on the diversity of herpetofauna in different areas of the country, as a first step towards conservation.

The present study was conducted at Giritale Nature Reserve from May 2006 to April 2008 with the objectives of identifying and assessing the amphibians and reptiles inhabiting the Giritale Nature Reserve, compare the species diversity between different types of habitats, species richness, and density of amphibians and reptiles in different types of habitats within the nature reserve.

Amphibians and reptiles were sampled monthly from May 2006 to April 2008 using quadrates, Visual Encounter Studies (VES), pitfall traps and opportunistic data collection method.

Four categories of habitats were identified as grasslands, home gardens, forests and paddy fields. A total of 431 individuals of amphibians representing the order Anura in five families (Bufonidae, Dicroglossidae, Microhylidae, Ranidae and Rhacophoridae)
\end{abstract}


were recorded. These included ten species of amphibians. A total of 489 individuals of reptiles representing the orders Squamata, chelonia in ten families (Colubridae, Elapidae, Uropeltidae, Viperidae, Agamidae, Geckonidae, Scinidae, Varanidae, Testudinidae, Pythonidae) were recorded. These included 31 species of reptiles. Fejervarya limnocharis was the most common amphibian species recorded and Calotes versicolor and Sitana ponticeriana had the highest relative abundance value for reptiles. Total number of amphibians observed was significantly different in the four habitat types $(t=14.28, d f=3, p<0.01)$. The greatest percentage of $29 \%(n=127)$ of amphibian individuals and highest diversity index was recorded in the paddy fields. However, the greatest percentage of reptile individuals was observed in the home gardens (59.9\%)

Total number of amphibians was significantly correlated with the ambient temperature in forests (Spearman's rank correlation $\mathrm{Z}=-0.51, \mathrm{P}<0.05$ ) and home gardens (Spearman's rank correlation $\mathrm{Z}=-0.52, \mathrm{P}<0.05$ ), but not correlated with the rainfall. Humidity also was a determinant factor for amphibians (Spearman's rank correlation Z $=-0.47, \mathrm{P}<0.001)$.

Reptile population was significantly correlated with the ambient temperature in the four different habitats but not significantly correlated with the rainfall (Spearman's rank correlation $\mathrm{z}=-0.18, \mathrm{p}>0.05$ ) or humidity (Spearman's rank correlation $\mathrm{z}=0.31$, $\mathrm{p}>0.05)$.

According to the results obtained it is obvious that the Giritale Nature Reserve is a rich habitat for amphibians and reptiles in the dry zone, Sri Lanka, hence warrants protection. 